\title{
Tıbbi cihazlara ilişkin patent ve faydalı model işlem süreçleri
}

\section{Patent and utility model registration processes for medical devices}

\author{
Ceren Bora Orçun
}

Biyomedikal Yüksek Mühendisi, Sınai Mülkiyet Uzmanı, Ankara

Fikri ve sınai mülkiyet hakları insan düşüncesinin ürünü olan yeniliklerin sahiplerine verilen ve bu yeniliklerin korunmasına ilişkin haklardır. Günümüzde tüm dünyada fikri ve sınai haklar değer yaratma açısından önemi yaygın olarak kabul görmüş kilit bir faktör halini almıştır. Başvuru sayılarındaki artışla desteklenen bu gelişme, tüm sektörlerde olduğu gibi tıbbi cihaz sektöründe de fark edilir derecede hızlanmaktadır. Tıbbi cihazlara ilişkin tüm "yenilikler" fikri mülkiyet haklarına konu olabilecek niteliktedir. Bu alandaki teknolojik gelişmeler öncelikle "patent" korumasını akıllara getirmektedir. Bu çalışmada sınai mülkiyet ve buluş kavramı ile patentle ilişkisi açıklanmış ve buluş örneklerine yer verilmiştir. Patent sisteminin ülkemizdeki tarihçesine ve özellikle 10.01.2017 tarihinde yürürlüğe giren Sınai Mülkiyet Kanunu'nda (SMK) yer alan patent ve faydalı model başvuru süreçlerine değinilmiştir. SMK kapsamında patentlenebilirlik kriterleri ve istisnaları açıklanmıştır. Ulusal ve uluslararası başvuru ve işlemler karşılaştırılmıştır. Tüm bu temel kavramların tanımları ve örneklerinin ardından biyomedikal sistemlere yönelik patent başvuruları, patentlenebilirlik şartları açısından değerlendirilmiştir. Tıbbi cihaz özelinde teşhis, tedavi ve cerrahi usullerin değerlendirmesi yapılmıştır. Disiplinler arası bir alan olan biyomedikal teknolojilerinin patent sınıflandırması hakkında bilgi verilmiştir. Son olarak da ön araştırmanın önemi ve araştırmada edinilebilecek bilgilere yer verilmiştir.

Anahtar sözcükler: patent; faydalı model; sınai mülkiyet hakları; inovasyon; araştırma-geliştirme; biyomedikal; tıbbi cihaz
Intellectual and industrial property rights are related to the protection of the innovations the rights given to the owners of these innovations. Today, intellectual and industrial property rights have become a widely recognized key factor in value creation all over the world. This development, supported by the increase in the number of IP applications, is noticeably accelerating in the medical device sector as in all sectors. All "innovations" regarding medical devices might be subject to intellectual property rights. Technological developments in this field primarily bring "patent" protection to mind. In this study, the concept of industrial property and invention, as well as its relation to patent protection are explained. The history of the patent system in our country and especially the patent and utility model application processes in the Industrial Property Law (IP Law), which entered into force on 10.01.2017, are mentioned. The patentability criteria and exceptions are explained within the scope of the IP Law. National and international applications and transactions have been compared. Following the definitions and examples of all these basic concepts, patent applications for biomedical systems were evaluated in terms of patentability requirements. Exceptions to patentability such as "methods for treatment of the human or animal body by surgery or therapy and diagnostic methods practiced on the human or animal body" were evaluated for medical devices. Information was given on the patent classification of biomedical technologies, which is an interdisciplinary field. Finally, the importance of preliminary research and the information that can be obtained in the patent search is given.

Key words: patent; utility model; industrial property rights; innovation; research and development; biomedical; medical device

\section{FIKRI HAKLAR VE SINAI MÜLKIYET HAKLARI}

İnsan düşüncesinin ürünü olan yeniliklerin korunmasına ilişkin haklar "fikri ve sınai mülkiyet hakları" adlarıyla anılmaktadır. Fikri ve sınai mülkiyet sistemi, yaratıcılığın ve yeniliğin gelişebileceği bir ortamı teşvik etmeyi amaçlamaktadır. Aynı zamanda bu hakların kamu yararını da gözetmektedir.[1] Telif hakları ile sınai mülkiyet haklarının ayrılmasının temeli iki uluslararası anlaşmaya dayanmaktadır. 20 Mart 1883 tarihinde imzalanan Paris Anlaşması'nın ikinci maddesine göre ${ }^{[2]}$, sınai mülkiyet hakkı olarak korumanın konusunu patentler, markalar, ticaret unvanları ve diğer ad ve işaretler teşkil etmektedir. Bunun yanında 1886 tarihinde imzalanan Bern Anlaşması'nda ise

- Iletişim adresi: Ceren Bora Orçun, Türk Patent ve Marka Kurumu, Hipodrom Caddesi No:13, 06560 Yenimahalle, Ankara Tel: 0312 - 3031620 e-posta: ceren.bora@turkpatent.gov.tr ORCID iD: 0000-0001-8019-2898

- Geliș tarihi: 8 Aralık $2020 \quad$ Kabul tarihi: 15 Aralık 2020 
edebi ve sanatsal eserlerin korunmasının ele alındığı görülmektedir. ${ }^{[3]}$ Ülkemizde de telif hakları ve sınai mülkiyet hakları korundukları kanunlar ve sorumlu olan kurum ve kuruluşlar bakımından da birbirinden ayrı değerlendirilmektedir. Türk Patent ve Marka Kurumu (TÜRKPATENT), "sınai mülkiyet hakları" olan patent, faydalı model, marka, tasarım, coğrafi işaret, geleneksel ürün adları ve entegre devre topoğrafyalarına ilişkin hakların tescili ve korumalarının sağlanması faaliyetlerini yürütmektedir. ${ }^{[4]}$ Telif haklarına ilişkin düzenlemeler ise Kültür ve Turizm Bakanlığı'nın hizmetleri arasında yer almaktadır. ${ }^{[5]}$

Her ne kadar ilgili kurumlar farklı olsa da bir yenilik ve fikirden bahsederken tüm bu fikri sınai hakların birlikte ele alınması gerekir. Her birinin fonksiyonunun ve sağladığı korumanın farklı olduğu göz önünde bulundurulmalıdır. Sınai mülkiyet haklarının değerlendirme ölçütlerinin yanı sıra tescil ve koruma süreleri de birbirinden farklıdır. Teknolojinin tüm alanlarında gündeme gelecek "yenilikler" fikri mülkiyet haklarının tamamına konu olabilecek niteliktedir. Ancak, teknoloji alanındaki gelişmeler öncelikle "patent" korumasını akıllara getirmektedir.

\section{PATENTLE íLişKILI TEMEL KAVRAMLAR}

Türk Dil Kurumuna göre patent ifadesinin tam karşılığı "buluş belgesi”dir.[ [6] Patentler buluşlara verilmektedir ve buluş kavramı temel olarak, insanların icatları veya geliştirdikleri teknikler olarak ifade edilebilir. ${ }^{[1]}$ Patent, kanun aracılığıyla buluşu yapanların ve patentin sahiplerinin tanınmasını veya maddi menfaat elde etmesini sağlamaktadır.

Buluş kavramı; doğada var olan bu işleyiş, kural veya maddeden yararlanarak, teknik bir soruna, teknik bir çözüm meydana getirilmesi olarak tanımlanabilir. Patente konu olabilecek buluş kavramının en çok karıştırıldığı diğer bir kavram da "keşif" kavramıdır. Buluş ve keşif birbirinden farklıdır. Keşif; "doğada var olan işleyişi, fizik kuralını, maddeyi vs. bulmak" anlamına gelmektedir ve patentlenebilecek bir konu değildir. Buluş tanımına bakıldığında cümlenin içinde birden çok sefer "teknik" ifadesinin yer aldığı dikkat çekmektedir. Bu kapsamda buluş; teknik unsurları tanımlanabilen göreceli olmayan bir problem için yine teknik unsurları ile tanımlanabilen bir çözümdür.

\section{Patentin Kısa Tarihçesi}

Ülkemizde ve tüm dünyada buluşların korunmasına ilişkin düzenlemeler yüz yılı aşkın bir süredir uygulanmaktadır. Bugünkü patent sisteminin temelini oluşturan ilk resmi düzenleme 1474 tarihinde Venedik'te yürürlüğe giren patent yasası belgesidir. Patent konusunda ülkemizdeki yasal korumanın temelini 1879 tarihli “ihtira Beratı Kanunu” teşkil etmiştir. İhtiranın anlamı; yeni bir şey bulma, türetme iken, berat ise; bir buluştan, bir haktan yararlanmak için devletçe verilen belge anlamına gelmekte ve ihtira beratı ise bilinen araç, gereçlerle ve yaratıcı güçle yeni bir şey bulana, bulduğu şeyden bir süre yalnız kendisinin yararlanması için devletçe verilen belgeyi ifade etmektedir.

İhtira Beratı Kanunu'nun ardından 1995 yılında yürürlüğe giren 544 sayılı Patent Enstitüsü Kuruluş ve Görevleri Hakkında Kanun Hükmünde Kararname, 551 sayılı Patent Haklarının Korunması Hakkında Kanun Hükmünde Kararname'nin (KHK) ve 551 sayılı Patent Haklarının Korunması Hakkında Kanun Hükmünde Kararname'nin Uygulama Şeklini Gösterir Yönetmelik kullanılmıştır. Ancak bu mevzuat 22.12.2016 tarihli ve 6769 sayılı Sınai Mülkiyet Kanunu'nun (SMK) 10.01.2017 tarihinde Resmi Gazetede yayınlanmasının ardından anılan kanun ile yürürlükten kaldırılmıştır.

Bugün Türk Patent ve Marka Kurumu'na ulaşan tüm başvurular SMK'ye tabi olsa da işlemleri devam eden başvurular kapsamında Mülga 551 Sayılı KHK'nın da günümüzde kullanımının devam ettiğini söylemek mümkündür. Bu kapsamda bir başvurunun hangi mevzuata tabi olduğuna karar verilmesinde başvuru tarihinin etkili olduğu bilinmelidir.

\section{Patentlenebilirlik Kriterleri}

Bilgiye ulaşmanın bu denli kolaylaştığı, teknolojik gelişmelerin yaygınlaştığı çağımızda fikri çaba ve zekâ ürünlerinin korunmasını hedefleyen patentler, uluslararası alanda yaşanan rekabet ortamının odağı haline gelmiştir. Ancak yaşadığımız bilgi çağında ilerleme açısından oldukça önemli yere sahip olan patentin gerçekten korunmayı hak eden yeni buluşlara verilmesi için bazı kriterler bulunmaktadır. Bu kriterler, niceliksel değerleme yöntemlerinin zorlukları ve eksiklikleri nedeniyle çoğunlukla nitel özelliklerle sınırlıdır.

Bir buluşun patent ile korunabilmesi için öncelikle başvuru konusunun patent verilebilir konu ve buluşlardan olması gerekir. Patent verilemeyecek konu ve buluşlar hakkında, her ülke istisnalarını belirleyerek yasa ile sınırlamalar getirmiştir. Ülkelerin patent kanunlarıyla uluslararası anlaşmalar arasında bazen küçük farklılıklar görülse de istisnaların genelde benzer konuları içerdiği görülmektedir.

6769 sayılı SMK'nin 82'nci maddesinde açıklandığı üzere, teknolojinin her alanındaki buluşlara yeni olması, buluş basamağı içermesi ve sanayiye uygulanabilir olması şartıyla patent verilmektedir.

Bu bölümde, patente ilişkin gerekliliklerin anlaşılabilmesi için yenilik, buluş basamağı içerme ve sanayiye 
uygulanabilir olma şartlarının daha ayrıntılı açıklamalarına yer verilmiştir. Açıklamalarda 6769 sayılı SMK'de yer alan tanımlar kullanılmıştır.

\section{Yenilik}

Patent verilebilme şartları arasında, kelime anlamının yaygın bilinmesi sebebiyle, en kolay anlaşılabilir olanı yenilik kavramıdır. Bu kavram buluşun "yeni" yani bilinen, hâlihazırda kullanılandan farklı olması anlamına gelmektedir. Burada atlanmaması gereken husus buluşun "mutlak yeni” olması kavramıdır. Başka bir deyişle, buluş sadece Türkiye'de değil, tüm dünyada yeni olmalıdır.

Patente konu olabilecek bir yenilik, teknolojinin her alanında yeni veya önemli ölçüde geliştirilmiş bir ürünü ya da bir süreci yani metodu ifade etmektedir. Buluşun yeni bir tek unsur içermesi buluşun yenilik kriterini sağlaması için yeterlidir. Yani ürünün, cihazın ya da metodun tamamen yeni olması şartı aranmaz, bir geliştirme de yenilik için yeterli sayılmaktadır.

SMK'nin 83'üncü maddesine göre yenilik "tekniğin bilinen durumuna dâhil olmayan buluş" olarak açıklanmaktadır. Tekniğin bilinen durumu ise aynı maddenin ikinci fikrasında "başvuru tarihinden önce dünyanın herhangi bir yerinde, yazılı veya sözlü tanıtım yoluyla ortaya konulmuş veya kullanım ya da başka herhangi bir biçimde açıklanmış olan toplumca erişilebilir her şeyi kapsar" olarak tanımlanmaktadır.

Yenilik kapsamında değinilebilecek bir diğer başlık da buluşa patent veya faydalı model verilmesini etkilemeyen açıklamalardır. SMK'nin 84'üncü maddesinde bu açıklamalar şu şekilde sıralanmıştır:

"Buluşa patent veya faydalı model verilmesini etkileyecek nitelikte olmakla birlikte, başvuru tarihinden önceki on iki ay içinde veya rüçhan hakkı talep edilmişse rüçhan hakkı tarihinden önceki on iki ay içinde ve aşağıda sayılan durumlarda açıklama yapılmış olması buluşa patent veya faydalı model verilmesini etkilemez:

a) Açıklamanın buluşu yapan tarafından yapılmış olması.

b) Açıklamanın patent başvurusu yapılan bir merci tarafından yapılmış olması ve bu merci tarafindan açıklanan bilginin;

- Buluşu yapanın başka bir başvurusunda yer alması ve söz konusu başvurunun ilgili merci tarafından açıklanmaması gerektiği hâlde açıklanması.

- Buluşu yapandan doğrudan doğruya veya dolaylı olarak bilgiyi edinmiş olan üçüncü bir kişi tarafından, buluşu yapanın bilgisi veya izni olmadan yapılan başvuruda yer alması. c) Açıklamanın buluşu yapandan doğrudan doğruya veya dolaylı olarak bilgi elde eden üçüncü kişi tarafından yapılmış olması."

Buluş sahibinin yayınları, varsa tezi, internette ürünün teknik detaylarının paylaşılmış olması ve benzeri tüm açıklamalar bu madde kapsamında değerlendirilmekte olup, buluşun yenilik kıstasında buluş sahibinin bu açıklamalarının patent ya da faydalı model verilmesini etkilememesi için en fazla on iki ay içinde Kuruma başvuru yapılmış olması beklenmektedir. Ancak, bu on iki aylık sürenin yalnızca Türkiye'de geçerli olduğu, farklı ülkelerde bu sürenin daha kısa olabileceği göz önünde bulundurulmalıdır. Bazı ülkelerde de başvuru tarihinden yayınlanmış ve halkın bilgisine sunulmuş herhangi açıklama sonucunda patent başvurusunun yenilik kriterini aşamayacağı unutulmamalıdır. Bu sebeple, tüm açıklamalardan önce Kurumun ilgili siciline başvurunun kaydedilmiş olması üçüncü kişilere Kuruma yapılacak başvurudan önce buluştan bahsedilmemesi önerilmektedir. Yenilik değerlendirmesinin dayanağı, uygulaması ve örneklerine ilişkin daha ayrıntılı bilgiye Türk Patent ve Marka Kurumu inceleme kılavuzundan ulaşılabilmektedir.

\section{Buluş basamă̆}

Buluş basamağı kavramı patentlenebilirlik kriterleri içinde en zor açıklanan kavramdır. Bunun sebebi, kavramın tanımı içinde yer alan, nispeten göreceli sayılabilecek bir kavramın bulunmasıdır. Bu da "aşikârlık" kavramıdır.

SMK'nın 83'üncü maddesinin dördüncü fikrasında buluş basamağı şu şekilde tanımlanmıştır: "tekniğin bilinen durumu dikkate alındığında, ilgili olduğu teknik alandaki uzmana göre aşikâr olmayan buluşun, buluş basamağı içerdiği kabul edilir”. 551 sayılı Mülga KHK'de ise "buluş basamağı" ifadesi yerine, değerlendirilmesi gereken esas kıstas olan "tekniğin bilinen durumunu aşan" ifadesi kullanılmıştır.

Buluş basamağının değerlendirilmesine, tekniğin bilinen durumuna dâhil olan, başka bir ifade ile yenilik kriterini sağlamayan unsurlar için ihtiyaç duyulmaz. Daha açık bir ifade ile; yeni olmayan bir unsurun kesinlikle buluş basamağı içermediği kabul edilmektedir. Ancak yeni olan unsurların tamamının buluş basamağı içerdiğini söylemek mümkün değildir. Buluş basamağı kavramı, tekniğin bilinen durumuna dâhil dokümanların, alanında uzman bir kişinin bilgi ve becerilerine dayanılarak birleştirilmesi sonucu değerlendirilen bir kriterdir. Bu birleştirmenin teknik alanında uzman bir kişi tarafından aşikâr olup olmaması değerlendirilmektedir. 
Aşikârlık kavramının göreceli olması unsurunun en aza indirilebilmesi için, Avrupa Patent Ofisi buluş basamağı kavramı için "problem çözüm yaklaşımı" kullanmaktadır. Bu yaklaşım kapsamında buluşu içeren unsurlar kapsamında, benzer amaca veya etkiye sahip teknikte bilinen en yakın doküman bulunur; buluşla bu doküman arasındaki farklar belirlenir; bu farkların yaratacağı teknik etki tanımlanır; önerilen çözümün aşikâr olup olmadığı belirlenir. Aşikârlığa ilişkin değerlendirmede "yapabilirdi/yapardı" ayrımı önem kazanmaktadır. Literatürde "could/would" yaklaşımı olarak tanımlanan bu ayrım, buluş değerlendirmesinin nesnel bir yaklaşımda değerlendirilmesine hizmet etmektedir.

\section{Sanayiye uygulanabilir olma}

Sanayiye uygulanabilir olma kriteri SMK'nin 83'üncü maddesinin altıncı fıkrasında "tarım dâhil sanayinin herhangi bir dalında üretilebilir veya kullanılabilir nitelikteyse, sanayiye uygulanabilir olduğu kabul edilir" olarak yer almaktadır.

Patentlenebilirlik kriterlerinden "sanayiye uygulanabilir olma" açıklanırken daha çok sanayiye uygulanamaz örnekler üzerinden açıklanabilmektedir. Fizik kurallarına aykırı, özellikle Newton yasalarına aykırı buluş örnekleri, sonsuz enerji kaynakları, devridaim makineleri, endüstride üretilmesi mümkün olmayacak buluşlar bu kapsamda değerlendirilmektedir.

\section{Faydalı Model Kavramı}

Faydalı model, patentlere oldukça benzeyen bir sınai mülkiyet kavramıdır. Patentte olduğu gibi buluşlara verilmekte olup ihtiyaçları karşılamak üzere öngörülen teknik çözümlere yönelik koruma sağlayan tescilli bir haktır. Faydalı model, çoğunlukla patentlere kıyasla daha basit, pratik ürünlere verilmektedir. Faydalı model koruması belirli ölçülerde patent korumasından farklııklar göstermektedir. Faydalı model ile patent arasındaki başlıca farklııklar tekniğin bilinen durumunun aşılması kriterinde, sürece ilişkin inceleme ve değerlendirmede ve koruma süresinde ortaya çıkmaktadır.

Türk Hukukunda faydalı modeller, 551 sayılı KHK'nin 154'üncü maddesi ve devamında yer alan hükümlerle düzenlenmiş ve uygulama alanı bulmuştur. 10.01.2017 tarihinde yürürlüğe giren 6769 sayılı Sınai Mülkiyet Kanunu'nun ise dördüncü kitap onuncu kısım 142 ila 145'inci maddeleri faydalı modele ilişkin hususları açıklamaktadır. Ancak dördüncü kitap bütünüyle değerlendirildiğinde patent ve faydalı modelin birlikte değerlendirildiği, sadece bu belirtilen hükümlerin faydalı modeller için özellikle ayrı uygulanacağı, çelişkili olmayan tüm maddelerin de patent ile ortak değerlendirileceği anlaşılmaktadır.
551 sayılı KHK ve 6769 sayılı SMK'de ortak olarak faydalı model korumasında yalnızca yenilik ve sanayiye uygulanabilirlik şartları arandığı belirtilmektedir. Patentte ise farklı olarak tekniğin bilinen durumunu aşma şartı da aranır. Bu nedenle de faydalı model belgesi tekniğin bilinen durumunun aşılması şartının incelemesine gerek duyulmadan verilebilmesi neticesinde patente göre daha kolay elde edilebilecek bir sınai mülkiyet hakkı olarak değerlendirilmektedir. Ancak 6769 sayılı SMK'nin 142'nci maddesi ikinci fikrasında yenilik değerlendirmesinde, buluş konusuna katkı sağlamayan teknik özelliklerin dikkate alınmayacağı açıkça belirtilmiştir. Bu ifade ile faydalı modellerde buluş basamağı kriteri aranmasa bile teknik katkı sağlamayan unsurların yenilik olarak dikkate alınmayacağını vurgulanmaktadır.

Aynı maddenin üçüncü fıkrasında ise faydalı modelle korunamayacak buluşlar;

a) Kimyasal ve biyolojik maddelere veya kimyasal ve biyolojik usullere ya da bu usuller sonucu elde edilen ürünlere ilişkin buluşlar,

b) Eczacılıkla ilgili maddelere veya eczacılıkla ilgili usullere ya da bu usuller sonucu elde edilen ürünlere iliş̧kin buluşlar,

c) Biyoteknolojik buluşlar,

ç) Usuller veya bu usuller sonucu elde edilen ürünlere ilişkin buluşlar olarak sıralanmaktadır.

Bu maddelerin dışında kalan tüm yeni ve sanayiye uygulanabilir buluşlar için düşük maliyetli ve hızlı elde edilebilecek faydalı model koruması sağlanabilir. İki belge arasındaki koruma süresi de farklıdır: Faydalı model belgesinin koruma süresi uzatılamayacak şekilde en fazla 10 yıldır. Patent dokümanında ise bu süre en fazla 20 yıldır.

\section{Patent Verilemeyecek Buluşlar}

6769 sayılı SMK'nin dördüncü kitap birinci kısım birinci bölümünde, 82'nci madde kapsamında patentlenebilir buluşlar ve patentlenebilirliğin istisnaları tanımlanmaktadır. Anılan maddenin ikinci fikrasında buluş niteliğinde sayılmayan konular:

a) Keşifler, bilimsel teoriler ve matematiksel yöntemler,

b) Zihni faaliyetler, iş faaliyetleri veya oyunlara ilişkin plan, kural ve yöntemler,

c) Bilgisayar programları,

ç) Estetik niteliği bulunan mahsuller, edebiyat ve sanat eserleri ile bilim eserleri,

d) Bilginin sunumu, 
olarak değerlendirilirken, daha önce (e) bendinde yer alan teşhis, tedavi usulleri ile cerrahi usullerin farklı bir kapsamda yer aldığı görülmektedir. Aynı maddenin üçüncü fikrasında patent verilmeyecek buluşlar şu şekilde sıralanmaktadır:

a) Kamu düzenine veya genel ahlaka aykırı olan buluşlar.

b) Mikrobiyolojik işlemler veya bu işlemler sonucu elde edilen ürünler hariç olmak üzere, bitki çeşitleri veya hayvan ırkları ile bitki veya hayvan üretimine yönelik esas olarak biyolojik işlemler.

c) İnsan veya hayvan vücuduna uygulanacak teşhis yöntemleri ile cerrahi yöntemler dâhil tüm tedavi yöntemleri.

ç) Oluşumunun ve geliş̧iminin çeşitli aşamalarında insan bedeni ve bir gen dizisi veya kısmi gen dizisi de dâhil olmak üzere insan bedeninin öğelerinden birinin sadece keşfi.

d) İnsan klonlama işlemleri, insan eşey hattının genetik kimliğini değiştirme işlemleri, insan embriyosunun sınai ya da ticari amaçlarla kullanılması, insan ya da hayvanlara önemli bir tıbbi fayda sağlamaksızın hayvanlara acı çektirebilecek genetik kimlik değiştirme işlemleri ve bu işlemler sonucu elde edilen hayvanlar.

Ayrıca maddenin altıncı bendi de "Üçüncü fıkranın (c) bendinde yer alan hüküm, aynı bentte sayılan yöntemlerin herhangi birinde kullanılan ürünler, özellikle madde ve terkipler hakkında uygulanmaz." olarak değiştirilmiştir.

Başvurunun öncelikle yukarıda belirtilmiş olan buluş niteliğinde sayılmayan konulara ya da patente konu olamayacak buluşlara girmediği değerlendirilmelidir. İstisnalar arasında sayılan "bilgisayar programları" ve "estetik niteliği bulunan mahsuller, edebiyat ve sanat eserleri ile bilim eserleri” Telif Hakları Kanunu kapsamında korunmaktadır. Ancak bilgisayar programının algoritmasını oluşturan fikrin ilgili teknik unsurlarla açıklanması halinde patentle korunabildiğini söylemek mümkündür.

Özellikle sağlık alanındaki buluşlar için genetik çalışmalar da istisnalar arasında görülse de kanun metninin ayrıntıyla irdelenmesi gerekir. Buluşun yalnızca keşif mi yoksa bu keşfin sağlanması ya da keşfin ardından ilaç ya da tedavide kullanılacak bir ürünü mü tanımladığı patent açısından önem kazanmaktadır. Sağlık alanında gerçekleşebilecek buluşlar için ayrıca "c) İnsan veya hayvan vücuduna uygulanacak teşhis yöntemleri ile cerrahi yöntemler dâhil tüm tedavi yöntemleri" maddesi dikkat çekmektedir. Ancak, bir buluşun patentlenip patentlenemeyeceğine yalnızca "konusuna” bakılarak karar verilmemektedir. Buluşla korunmak istenen unsurların açıklandığı "istemlerin" nasıl düzenlenmiş olduğu bu kapsamda büyük önem arz etmektedir. Örneğin, teşhis tedavi yöntemleri yani işlem basamakları şeklinde düzenlenmiş bir buluş patentlenemeyecektir. Ama bir tıbbi cihazın insan ya da hayvan vücudu dışında gerçekleştireceği işlemler patentlenebilir. ${ }^{[7]} \mathrm{Bu}$ konu "Tıbbi Cihazlara ilişkin patent başvurularında dikkat edilmesi gereken hususlar" başlığı altında daha ayrıntılı incelenmiştir.

\section{TIBBi CIHAZ PATENTLERi}

Tıbbi cihaz teknolojisi, başka bir ifade ile medikal teknoloji, insan sağlığıyla ilgili tüm hastalık ve durumların, tanısı, izlenmesi ve tedavisi için kullanılan her türlü teknolojiyi kapsamaktadır. Tıbbi cihazların sınıflandırılması tüm dünyada problemli bir alan olarak görülmektedir; bunun sebebi çok geniş bir ürün yelpazesi bulunması ve hem sarf hem de demirbaş listesinde sayılabilecek ürünleri içinde barındırmasıdır. Yara bantlarından şırıngaya, lateks eldivenlerden gözlüklere alışılmış günlük nesneleri kapsadığı gibi, tekerlekli sandalyeden işitme cihazına, hamilelik testinden kan şekeri ölçüm cihazına tüm alanlarda teknolojinin sağlık alanındaki tüm uygulamalarıyla karşımıza çıkmaktadır. İleri teknolojiye örnekleri ise tüm vücut tarayıcıları, ultrasonografi cihazları, yaşam destek üniteleri, kalp kapakçıkları ve kalp pili gibi implante edilebilen cihazlar, nörostimülatörler ile diz ve kalçalar için yapay eklemleri içermektedir. Hâlihazırda mevcut 500,000'den fazla tıbbi teknoloji ürünü bulunmaktadır ve hepsinin ortak amacı: insanların hayatlarını iyileştirmek, geliştirmek ve yaşam kalitesini arttırmaktır.

Türkiye'de son yıllarda tıbbi cihazlar sektöründe (tıp teknolojisinde) yeterli üretim ve araştırma konusunda önemli yasal ve kurumsal gelişmeler yaşanmaktadır. Dünya nüfusunun gittikçe yaşlanması, kronik veya yaşam koşullarına bağlı hastalıklardaki artış ve çeşitlilik, bilimin ilerleme ve alım gücünün artması tıbbi cihaz endüstrisinin büyümesindeki başlıca faktörlerdir. ${ }^{\left[{ }^{[8]}\right.}$ Tıbbi cihazlar sektörü, firma sayısı, yeni ürün üretim kapasitesi ve pazar hacmi bakımından büyüyen ve potansiyeli artan bir sektördür. ${ }^{[9]}$

Dünyada tıbbi cihaz alanında tarihe geçen ilk patent 1796 yılında ABD menşeli Perkins'in aldığı "Metalik Traktörler" başlıklı buluşudur. ${ }^{[10]}$ Buluş, baş ağrısı, romatizma, deformitelerin tedavisinde vücuttan toksik elektrik çekmek için kullanılan, üç inç uzunluğun$\mathrm{da}$, biri demirden ve biri pirinçten oluşan iki adet sivri metal çubuktan oluşur. ${ }^{[11]}$ Yine mihenk taşı niteliğinde önemli buluşlardan birisi 1844 'de tarihe geçen ilk derialtı şırıngadır. ${ }^{[10]}$ 
Ülkemizde tıbbi cihaz alanında patent koruması elde eden ilk patent Westinghouse Electric Corp.'a ait 69/17019 numaralı "Termometre" başlıklı patenttir.

Günümüzde medikal teknoloji, patent alanında en fazla ilerleme gösteren sektörler arasında anılmaktadır. Dünya Fikri Mülkiyet Teşkilatı (WIPO), PCT 2020 yıllık raporunda yer alan istatistiklere göre patent başvurularının sayısına göre teknik alanlar Tablo 1 'de sıralanmıştır. ${ }^{[12]}$ Önceki yıllar ile kıyaslandığında dijital haberleşmenin çok büyük bir artış gösterdiğini söylemek mümkündür. Bundan önceki yıllarda medikal teknoloji üst üste en yüksek başvuru alınan alan olarak karşımıza çıkmaktaydı. Bu yıl da medikal teknolojilerin önceki seneye göre $\% 0,9$ artış gösterdiği ve ikinci sırada yer aldığı kaydedilmiştir. Bu alanda başvuru sayılarının ilaç ve biyoteknoloji alanında gerçekleştirilen buluşların sayısından daha fazla olduğu da dikkat çekmektedir.

Medikal teknoloji ile ilaç ve biyoteknoloji alanındaki başvurular karşılaştırıldığında da biyomedikal alanındaki Avrupa Patentlerinin sürekli artış eğiliminde olduğu görülmektedir. Biyomedikal sektörü, ilaç ve biyoteknoloji alanlarına göre daha fazla artış göstermiştir. ${ }^{[12,13]}$ Avrupa'da toplam sağlık harcamalarının dağılımına bakıldığında, yatarak tedavi ve ayakta hasta bakımı başığının \%76,6 ile en büyük paydayı oluşturduğu görülmektedir. îlaç ve diğer dayanıklı olmayan tıbbi ürünler \%16'lık bir yüzdeyi sağlarken \%7,4'ün ise medikal teknolojilere ayrılan harcamalar olduğu görülmektedir. ${ }^{[13]}$

Tablo 1. Patent başvurularında ilk 10 teknik alan WIPO, PCT, 2019 patent başvuru sayıları ${ }^{[12]}$

\begin{tabular}{|ll}
\hline 14,175 & DijiTAL HABERLEŞME \\
\hline 13,833 & MEDIKAL TEKNOLOJi \\
\hline 12,774 & BíGISAYAR HABERLEŞME \\
11,255 & ELEKTRIK MAKINELERI, APARATLARI, ENERJi \\
9,635 & TAŞIMACILIK \\
9,045 & ÖLÇÜM \\
\hline 7,697 & ILAÇ \\
\hline 6,801 & BIYOTEKNOLOJi \\
\hline 6,436 & DiĞER ÖZEL MAKINELER \\
6,167 & ORGANIK KIMYA \\
\hline
\end{tabular}

\section{Patent Sınıflandırması}

Tıbbi cihaz üretim sektörünün yakında tanıdığı tıbbi cihaz direktifleri kapsamında bakıldığında, Şekil 1, tıbbi cihazların ve in vitro tıbbi tanı cihazlarının risk gruplarına göre şematik olarak sınıflandırmaktadır. ${ }^{14]}$ Ancak, patent sınıflandırmasının tıbbi cihaz direktiflerinde tanımlı bu sınıflandırmalarla doğrudan bir ilişkisi bulunmamaktadır.

Patentlerin sınıflandırması, patent dokümanlarında yer alan teknolojilerin takibinin ve patent dokümanlarına erişimin kolaylaştırılması, yenilik ve buluş basamağı değerlendirmesinde önceki tekniklere ulaşıma yardımcı olması, araştırma ve geliştirme yapılan alandaki mevcut tekniklere düzenli bir şekilde ulaşmanın hızlanması ve kolaylaştırılması amaçlarına hizmet etmektedir. Bu kümelendirme ile patentlerin teknolojik alanlara göre istatistiklerinin de oluşturulmasının mümkün kılınmaktadır.

Ulusal ofisler tarafından hazırlanmış olan sınıflandırma sistemlerinin en önemlileri, ABD, Almanya, Japonya ve İngiltere tarafından hazırlanmış olan sınıflandırma sistemleridir. ${ }^{[15]}$ Patent bilgisinin, dünya çapında yayılması söz konusu olduğundan, uluslararası ortak bir sınıflandırma sistemine ihtiyaç duyulmuş ve 19 Aralık 1954 tarihli Patentlerin Uluslararası Sınıflandırmasına Dair Avrupa Sözleşmesi ile dünyada ortak bir patent sınıflandırma sisteminin oluşturulması konusunda önemli bir adım atılmıştır. ${ }^{[16]} 1971$ tarihinde imzalanmış ancak 1975 tarihinde yürürlüğe girmiş olan 'Uluslararası Patent Sınıflandırması ile İlgili Strazburg Anlaşması' na Türkiye 1 Ekim 1996 tarihinde taraf olmuştur. ${ }^{[17]}$ Türk Patent ve Marka Kurumu veri tabanında kayıtlı bulunan patent ve faydalı modeller, Uluslararası Patent Sınıflandırma Sistemi'ne (IPC) göre sınıflandırılmaktadır.

Ülkemizde de kullanılan IPC'nin 8 ana başlığı bulunmaktadır. Bölüm başlığı olarak adlandırılan bu sekiz alan aşağıdaki gibi sıralanmıştır:

A İnsan ihtiyaçları

B Operasyonları uygulama; Nakletme (Taşıma)

C Kimya; Metalurji

D Tekstil, Kâğıt

E İnşaat

F Mekanik Mühendisliği; Aydınlatma; Isıtma; Silahlar; Tahrip Malzemeleri

\section{G Fizik}

H Elektrik

Bölüm, sınıf, alt sınıf ve grup bilgileri ise IPC'nin hiyerarşisini tanımlamaktadır. IPC'nin hiyerarşik 


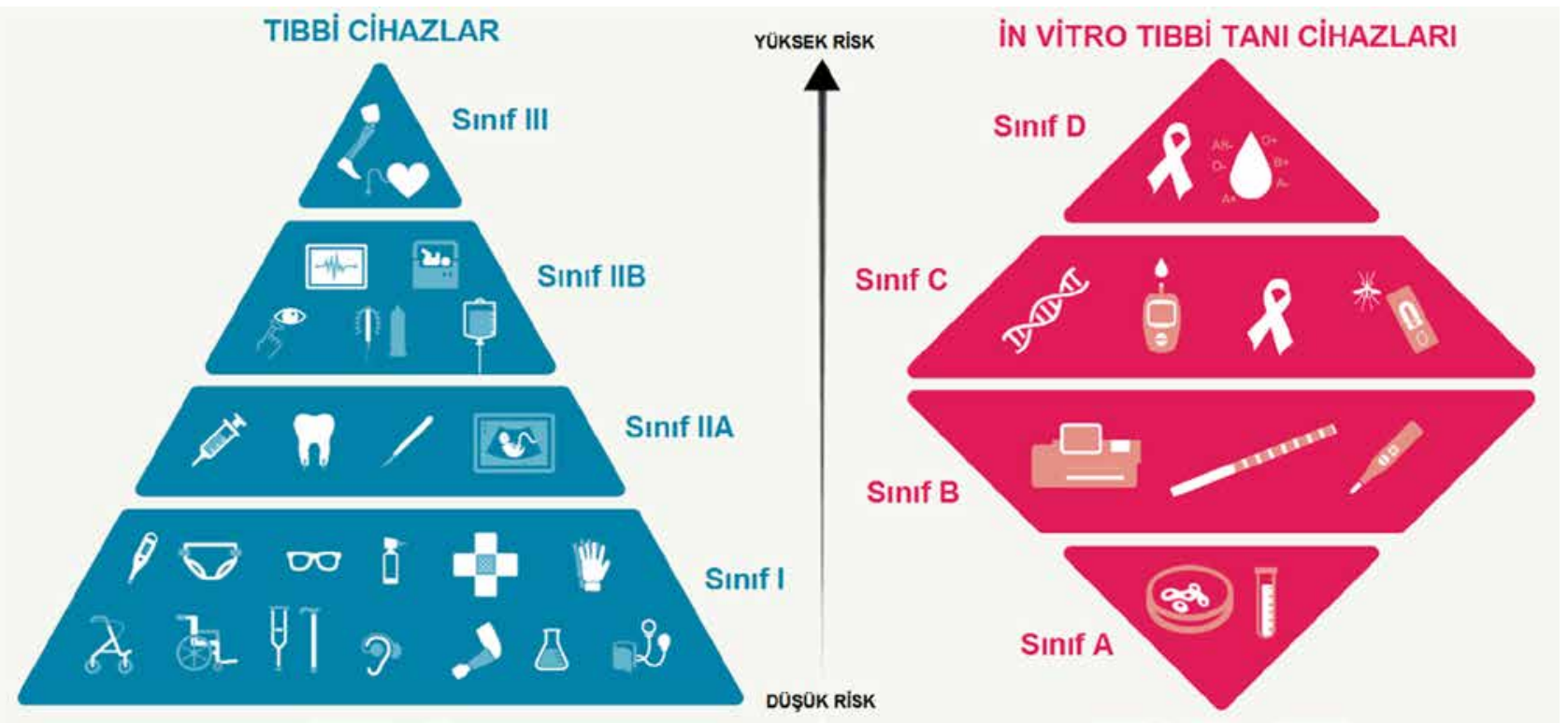

Şekil 1. Medikal teknoloji çeşitliliği ve sınıflandırması. ${ }^{[14]}$

yapısı Şekil 2'de gösterilmektedir. Tablo 2 ise bir tıbbi cihaz için IPC sınıflandırmasının hiyerarşik sıralamasını göstermektedir.

IPC sınıflandırmasına göre biyomedikal sistemlere yönelik patentler özellikle A61 sınıfının altında (B, C, D, $\mathrm{F}, \mathrm{G}, \mathrm{H}, \mathrm{J}, \mathrm{L}, \mathrm{M}, \mathrm{N})$ ve $\mathrm{H} 05 \mathrm{G}$ olarak sıralanmaktadır. ${ }^{[18]}$

IPC sadece grup bilgisiyle değil alt gruplar da kendi içinde hiyerarşik yapıda olacak şekilde sınıflandırılmaktadır. Bu alt grup içindeki sıralama tanımın başında bulunan noktalarla derecelendirilmekte ve her bir nokta ile daha spesifik bir başlığa inilmektedir. Ortopedi ve travmatoloji alanında başka bir örnek olarak da implantlara ilişkin IPC sınıflandırılması verilebilir. Tablo 3 bu sınıflandırma örneğini yansıtmaktadır.

Şekil 3'te tıbbi cihaz alanında Türkiye'de gerçekleştirilen patent başvurularının özellikleri sıralanmaktadır. Tıbbi cihaz teknolojileriyle ilişkili Tablo 2'de açıklamaları yer alan IPC'ler için 1995-2020 (ilk 10 ay) tarihleri arasında bir sorgu düzenlenerek Kurumumuz bilgi

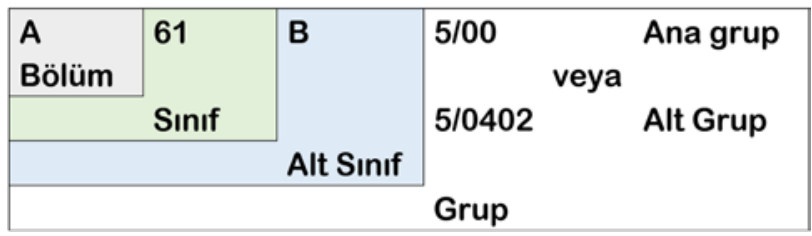

Şekil 2. IPC'nin hiyerarşik yapısı. işlem birimi aracılığıyla veriler çekilmiş ve istatistiklerin derlenmesi bu şekilde sağlanmıştır.

Görüleceği üzere, tıbbi cihaz sektöründe 1995 yılından bu yana 17728 adet başvuru kaydedilmiştir. Bu başvuruların \%72,6'sı tescil olmuştur. Tıbbi cihaz alanında halihazırda geçerli olan 9766 adet başvuru vardır. Bu da tüm başvuruların \%55,1'ine tekabül etmektedir. Ancak mevcut başvurular daha ayrıntılı incelendiğinde başvuruların büyük yüzdesini Avrupa patent başvuruları, başka bir ifade ile yabancı başvuru sahipli patentler oluşturmaktadır. Avrupa'da tescillendikten sonra ülkemizde koruması sağlanan bu patent başvurularının hemen hemen tamamının (\%99,1 oranında) tescillenmiş olduğu bilinmektedir. Oysa ulusal aşamada tescil süreci tamamlanan başvuruların yalnızca \%41,3'ü belge almıştır. Başvuruların \%14,8'ini faydalı modeller oluştururken $\% 85,2$ 'lik kısmı patenttir. Bu alanda 2000 yılından bu yana 701 adet PCT ulusal sahaya giren patent bulunmaktadır.

Şekil 4'te ise yıllar bazında başvuru ve tescil oranlarını göstermektedir. Yerli ve yabancı başvurular; doğrudan TÜRKPATENT'e yapılan başvuru ve EPC ile tescillenmiş başvuru olarak ayrılmaktadır. Şekilde yer alan çizgi grafik "yerlilik oranını" temsil etmektedir. Bu istatistiksel veriye göre, yerlilik oranının \%50'lere yaklaşmış olduğu görülmektedir. 2000'li yılların başında \%30-35'ler seviyesinde seyreden bu grafikteki artış ülkemizde bu alandaki çalışmaların artığının bir kanıtıdır. Ayrıca tıbbi cihaz alanında 2010 yılında yapılan başvurularla 2019 yılında yapılan başvuruların sayısı 
Tablo 2. Tıbbi cihazlar için IPC sınıflandırmaları

\begin{tabular}{|c|c|}
\hline A & INSAN IHTIYAÇLARI \\
\hline A 61 & TIBBi VEYA VETERINER BILIMI; HIJYEN \\
\hline A 61 B & Teşhis; cerrahiye; tanımlama \\
\hline A $61 \mathrm{C}$ & Dişçilik; oral veya diş hijyeni \\
\hline A $61 \mathrm{D}$ & Veterinerlik aletleri, araçları, aygıtları veya yöntemleri \\
\hline A $61 \mathrm{~F}$ & $\begin{array}{l}\text { Kan damarına takılabilen filtreler; protez; ortopedik, hemşirelik veya gebelik önler (kontraseptif) cihazlar; pansuman; göz veya } \\
\text { kulak tedavi veya korunması; bandaj, sargı veya emici pedler (tamponlar); ilk yardım kitleri }\end{array}$ \\
\hline A 61 G & Hastaların nakli veya barınması; ameliyat masaları veya koltukları; dişçi koltuğu; cenaze cihazları/nakil cihazları/aparatları \\
\hline A $61 \mathrm{H}$ & $\begin{array}{l}\text { Fizik terapi araçları, örneğin vücutta refleks noktalarının belirlenmesi için kullanılan veya uyarııı aletler (stimülatör); suni } \\
\text { teneffüs; masaj; özel terapi veya hijyen amaçlı veya spesifik vücut bölümleri için banyo cihazları }\end{array}$ \\
\hline A $61 \mathrm{~J}$ & $\begin{array}{l}\text { Tıbbi veya farmakolojik amaçlar için özel olarak uyarlanan konteynerler; farmakolojik ürünlerin fiziksel veya zerk formlarına } \\
\text { getirilmesi için özel olarak uyarlanan cihaz veya yöntemler; gıda veya ilacın ağız yoluyla verilmesi cihazları; bebek rahatlatıcı } \\
\text { araçlar; tükürük alma cihazları. }\end{array}$ \\
\hline A $61 \mathrm{~L}$ & $\begin{array}{l}\text { Genel olarak madde veya nesnelerin sterilizasyonu ile ilgili yöntem veya araçlar; dezenfeksiyon, sterilizasyon veya havanın } \\
\text { deodorizasyonu, bandaj, sargı, emici ped veya cerrahi maddelerin kimyasal özellikleri, bandaj sargı, emici ped veya cerrahi } \\
\text { eşyalar ile ilgili maddeler }\end{array}$ \\
\hline A $61 \mathrm{M}$ & $\begin{array}{l}\text { Vücut içine veya üstüne takılan cihazlar; Vücuda tıbbi cihaz takılması veya çıkarılması ile ilgili cihazlar; uyutma veya bayıltma } \\
\text { işleminin başlatılması veya sona erdirilmesi ile ilgili olarak kullanılan cihazlar }\end{array}$ \\
\hline A $61 \mathrm{~N}$ & Elektroterapi; magnetoterapi; ışın tedavisi; ultrasonik terapi \\
\hline $\mathbf{H}$ & ELEKTRIK \\
\hline $\mathrm{H} 05$ & DiĞER ŞEKILDE VERILMEYEN ELEKTRIK TEKNIKLERI \\
\hline H 05 G & $\begin{array}{l}\text { X-ray Tekniği (radyasyon tanısı için cihaz A61B 6/00; X-ışını tedavisi A61N; X-ışını testi G01N; X-ışını fotoğrafçılığı için cihaz } \\
\text { G03B; filtreler, dönüştürme ekranları, mikroskoplar G21K; X-ışını tüpleri H01J 35/00; X-ışını girdisi H04N 5/321 olan TV } \\
\text { sistemleri) }\end{array}$ \\
\hline
\end{tabular}

Tablo 3. IPC sınıflandırmasının hiyerarşik sıralaması örneği; ortopedi/femur başları IPC'si

\begin{tabular}{|c|c|}
\hline $\mathbf{A}$ & INSAN IHTIYAÇLARI \\
\hline A61 & TIBBI VE VETERINER BILIMI; HIJYEN \\
\hline A61F & $\begin{array}{l}\text { Kan damarına takılabilen Filtreler; Protez; Ortopedik, Hemşirelik veya gebelik-önler (kontraseptif) cihazlar; Pansuman; Göz } \\
\text { veya kulak tedavi veya korunması; Bandaj, sargı veya emici pedler (tamponlar); ilk yardım kitleri }\end{array}$ \\
\hline A61B 2/00 & $\begin{array}{l}\text { Kan damarlarına implante edilebilen filtreler; Protezler, yani vücudun bölümleri için yapay ikameler veya ikameler; Bunları } \\
\text { vücuda bağlamak için aletler; Vücudun boru şeklindeki yapılarına açıklık sağlayan veya çökmesini önleyen cihazlar, örn., } \\
\text { stentler }\end{array}$ \\
\hline A61F 2/02 & - Vücuda yerleştirilebilen protezler \\
\hline $\mathrm{A} 61 \mathrm{~F} 2 / 30$ & •• Eklemler \\
\hline A61F 2/32 & •.. Kalça için \\
\hline A61F 2/36 & •..• Femur başları \\
\hline
\end{tabular}

karşılaştırıldığında 10 yılda \%173 oranında bir artış kaydedilmiştir.

Türkiye'ye yapılan patent başvurularının rüçhan ülkeleri değerlendirildiğinde ise en yüksek oranın $A B D$ menşeli patentler olduğu görülmektedir (Şekil 5). İkinci sırayı Avrupa Patentleri alırken Almanya, İngiltere ve Fransa sırayı takip etmektedir. Türkiye rüçhanlı patent başvurularının sıralaması ise İtalya, Japonya ve İsveç’i takiben dokuzuncu olarak görülmektedir. İlk onda yer alan diğer ülke ise Çin'dir.
Türkiye'deki biyomedikal sistemlere yönelik patent başvurularının IPC'leri ise Şekil 6'da gösterilmektedir. Şekil 6, 1995-2020 yılları arasındaki toplam IPC dağılımlarını ve bu alanlardaki başvuru sayılarını göstermektedir.

Türkiye'deki patent başvurularının IPC sıralamasının dağılımına bakıldığında; Türkiye'deki en yüksek eğilimin A61B ile "Teşhis; Cerrahiye; Tanımlama" başlığı altındaki sistemlerle ilgili olduğu görülmektedir. İkinci sırada ise "Vücut içine veya üstüne takılan cihazlar; Vücuda tıbbi 

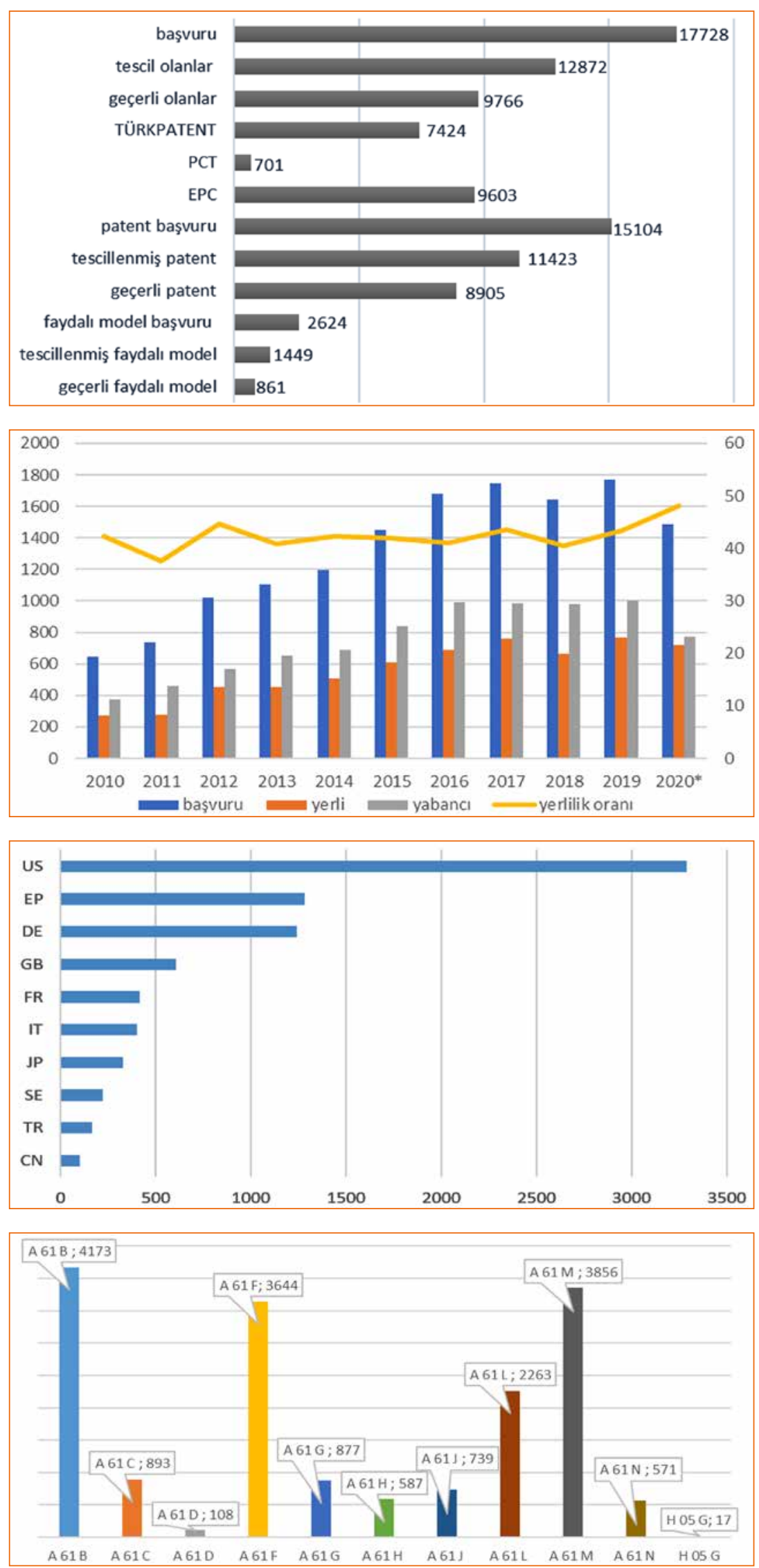

Şekil 3. Türkiye'de tıbbi cihaz patentleri (TÜRKPATENT, Bilgi ișlem Dairesi Bașkanlığı, $A 61$ (B, C, D, $F, G, H, J, L, M, N)$ ve H05G sınıfları, 1995-2020 (ilk 10 ay) tarihleri arasında Kuruma gerçekleştirilen başvurular üzerinden istatistikler oluşturulmuştur).

Şekil 4. Türkiye'de tıbbi cihaz patent ve faydalı modelleri: yerli yabancı toplam başvuru sayıları (TÜRKPATENT, Bilgi İ̧̧lem Dairesi Başkanl/ğı).

Şekil 5. Türkiye'de tıbbi cihaz alanında yapılan başvuruların rüçhan ülkeleri sıralaması (TÜRKPATENT, Bilgi işlem Dairesi Başkanlığı).

Şekil 6. Türkiye'de tıbbi cihaz alanında yapılan başvuruların IPC dağılımları (TÜRKPATENT, Bilgi işlem Dairesi Başkanlığı). 
cihaz takılması veya çıkarılması ile ilgili cihazlar; uyutma veya bayıltma işleminin başlatılması veya sona erdirilmesi ile ilgili olarak kullanılan cihazlar" başlığı ile A61M gelmektedir. "Kan damarına takılabilen Filtreler; Protez; Ortopedik, Hemşirelik veya gebelik-önler (kontraseptif) cihazlar; Pansuman; Göz veya kulak tedavi veya korunması; Bandaj, sargı veya emici pedler (tamponlar); ilk yardım kitleri" grubunun temsil edildiği A61F ise üçüncü sırada yer almaktadır. Tıbbi cihaz alanında tüm dünyadan yayınlanan patent verileri ile kıyaslandığında ülkemiz istatistiklerinin büyük ölçüde dünya verileri ile uyumlu olduğu bilinmektedir. Benzer şekilde bu verilerin Türkiye Tıbbi cihaz ithalat ihracat verileri ile de uyumlu olduğunu söylemek mümkündür. ${ }^{[7]}$

\section{PATENT/FAYDALI MODEL IŞLEM SÜREÇLERi}

Patentin korunması, başvuru tarihinden itibaren en fazla 20 yıl süre ile patent sahibine belgenin geçerliliğini sürdürdügüu sürece buluşa ilişkin bir tekel hakkı verir. Bu durum, buluşu izinsiz kullanan üçüncü kişilere karşı yasal işlem yapılabileceği anlamına gelir. Patentler ayrıca yatırım amaçlı da kullanılabilen değerli evraklardır; buluş lisanslanabilir veya devredilebilir.

Patentle sağlanan tekel hakkının sağlanması için gerekli süreç ülkemizde ortalama 3,6 yıl sürebilmektedir. Bu sürecin uzun olmasının yanı sıra, karşıııkı bir açıklama ve yazışma süreci olduğu bilinmelidir. Başvuru evraklarının hazırlanması bu sürecin öncesinde, süreye dâhil edilmemiş bir aşamadır ve ilk teslim edildiği hali ile tarifnamedeki açıklamalar buluşun kapsamını belirlediği için belki de en önemli aşamadır.

Patent sürecinde başvurunun ardından şekli bir kontrol yapılır. Sonrasında araştırma talebine cevaben yakın dokümanların sıralandığı bir araştırma raporu hazırlanır. Araştırma raporunda değinilen dokümanların kategorileri önemlidir. Raporlarda yaygın olarak karşılaşılan kategoriler $\mathrm{X}, \mathrm{Y}$ ve $\mathrm{A}$ kategorileridir. $\mathrm{X}$ kategorisinde değerlendirilen bir doküman, karşısında sıralanan istemler için yenilik ya da buluş basamağı açısından karşıt bir dokümandır. Y kategorisinde değerlendirilen bir doküman, buluş basamağı için başka bir dokümanlar birlikte düşünüldügüünde buluşun patent almasına karşıt olacak dokümanı ifade eder. A kategorisinde değerlendirilen dokümanlar ise yenilik ya da buluş basamağı açısından buluşla ilgili tüm unsurları karşılamadığı belirtilen dokümanları ifade etmek için kullanılır. Sürecin devamında bu dokümanlar ayrıntısıyla incelenerek varsa farklılıklar açıklanması, karşı görüş ve değişikliklerle inceleme talebi yapılmalıdır. İnceleme raporu, araştırma ve inceleme uzmanlarınca buluşun istemler bazında patent alıp alamayacağının değerlendirildiği rapordur. İncelemeye ilişkin bildirimlere de Kanun kapsamında cevap hakkı bulunmaktadır.
Patent sürecinde değişiklikler ve açıklamalar yapılırken tarifnamenin ilk kapsamının aşılamayacağı bilinmelidir. Kapsamı aşmayacak şekilde yapılacak değişiklikler ve açıklamalar ile patentin son hali verilebilmektedir. Ayrıca, ana başvurudan sonra ek başvurular kapsamında yeni unsurlar da dâhil edilebilmesi mümkündür.

$\mathrm{Bu}$ kapsamda gerçekleştirilecek başvurunun tüm aşamaları TÜRKPATENT internet sayfasında bulunan hizmetlerden "Patent Bilgilendirme" başlığı altında yayınlanan "Patent-Faydalı Model Başvuru Kılavuzu" ve "Patent İnceleme Kılavuzu" incelenmelidir. ${ }^{[19]}$

Patent koruması elde edebilmek için tüm dünyada yeni ve bilinen tekniklerle kolaylıkla ortaya konulamayacak bir fikir sahibi olmak gerekmektedir. Fikrinizin yeni olup olmadığını kontrol etmek için başka araştırmacıların teknik alanda ne tür faaliyetler gerçekleştirdiğinin araştırılması oldukça önemlidir. Araştırma kapsamında karşılaşılan benzer teknik çözümlerden buluşunuzun farklılıkları tarifnamede açıklanarak ortaya konulmalıdır.

Araştırması ve tüm fikrine sahip olunan bir ürünün/ cihazın tek eline sahip olmak buluşun sanayileştirilmesi aşamasında şüphesiz önemli bir unsurdur. Aynı derecede önemli başka bir husus ise, yatırımlardan önce başkasının yeni ürününüzü ihlal edebilecek geçerli patentlere sahip olup olmadığını kontrol etmektir.

\section{Ön Araştırma}

Başvurudan ve hatta herhangi bir yatırımdan önce, şu anda, herhangi bir üçüncü kişinin ürününüzü pazarlamanıza engel olacak haklara sahip olup olmadığının öğrenilmesi gerekir. Bu araştırmanın düzenli olarak gerçekleştirilmesinde fayda bulunmaktadır. Bu araştırma sayesinde hem başkalarının tekelinde bulunan teknolojilerin üretimine yatırım yapılması engellenmiş olur hem kendi geliştirdiğiniz patentlerin ihlal edilip edilmediğinin takibi sağlanmış olur. Bu araştırma dâhili olarak organize edilebileceği gibi harici bir ajansın da bu alanda düzenli bilgi sağlaması mümkündür. Araştırmanın bu alandaki teknik terminolojiye ve patent sistemine hâkim deneyimli bir personel tarafından yapılmalıdır. Aslında araştırma kapsamında erişilecek tüm patentlere internet üzerinden ücretsiz olarak erişmek mümkündür. Üstelik bu değerli bilgi kaynağının yani patent dokümanlarında açıklanan teknik çözümlerin \%94'ünün kullanımı serbesttir. Patent araştırmasının yapılabileceği birçok arayüz bulunmaktadır.

Türk Patent ve Marka Kurumunun internet sayfası üzerinden Türk patentlerine ücretsiz olarak erişmek mümkündür ${ }^{[19]}$. Araştırma ile buluşunuzun Türkiye'de korunan patentler arasında olup olmadığını kontrol 
etmenin yanı sıra TÜRKPATENT'e gerçekleştirilecek başvurunuz için örnek başvuruları bulmak amacıyla da incelenmesi önerilmektedir.

Ancak tüm dünyada yeni olması gerek buluşunuzun araştırması için Türk patentlerinin incelenmesi yeterli olmayacaktır. En yaygın kullanılan araştırma arayüzleri arasında Google Patents (Patents.Google) ${ }^{[20]}$ ve 120 milyondan fazla patent verisine erişilebilen Avrupa Patent Ofisinin patent araştırma sayfası (ESPACENET) ${ }^{[21]}$ sayılabilir. Bu sayfalardan İngilizce dilinde yapılacak araştırma ile İngilizce diline çevrilmiş hali ile tüm dünyada yayınlanan tüm patent başvurularına ulaşmak mümkündür.

Arama için olağan yaklaşım, patent sınıflandırma kodları ve anahtar kelimeler ile bunların kombinasyonunu kullanılabilir. Arama, aynı araştırma alanında çalıştıkları düşünülen belirli şirketlere ve/veya buluş sahiplerine yoğunlaşarak da gerçekleştirilebilir.

Aşağıda araştırmayı kapsamlı hale getirmek için gerekli unsurları içeren kontrol listesi sunulmuştur:

- araştırma yapılacak ülkelerin belirlenmesi,

- anahtar kelimelerin (ve eşanlamlılarının) seçilmesi,

- araştırma diline karar verilmesi (en yaygın kullanılan İnilizce),

- aranacak patent sınıflarının belirlenmesi (diğer yakın alanlarda ilgili patentlerin araştırılması da gerekebilir),

- varsa, rakip şirketler, özellikle aranacak başvuru/ buluş sahiplerinin belirlenmesi,

- ürünün/cihazın gerçekten yeni olup olmadığının değerlendirilmesi; var olan bir ürünün veya teknik konunun iyileştirilmesi için hâlihazırda var olanların tanımlanması,

- eğer benzer çalışmalar var ise, araştırmanın üzerinde yoğunlaşması gereken yeni özelliklerin belirlenmesi.

Araştırma neticesinde erişilen dokümanlar sayesinde yeni referanslara ulaşılması mümkün olabilmektedir. Ulaşılan dokümana benzer dokümanlar, dokümanın sınıflandırmasında kullanılan yeni bir IPC kodu, kelime türetmede yakın dokümanda kullanılan terimler bir sonraki araştırma için bizlere yol göstermektedir. Ön araştırma adı verilen bu araştırmaların ardından, buluş için patent korumasının gerekli olup olmadığı değerlendirilmelidir.

İlgili patentlerin durumu, ilgilenilen ülkelerdeki her bir ulusal patentin geçerliliği kontrol edilmelidir. Patent sahibinin yıllık sicil kayıt ücretini ödemediği ve potansiyel olarak çalışmanızı bloke eden patentin geçerliliğini yitirmiş olması mümkündür. Ayrıca engel konumundaki patent, mahkeme kararı sonucunda üçüncü bir tarafça feshedilmiş de olabilir. Ayrıca patentlerin en fazla 20 yıl süre ile koruma sağlayabileceği de unutulmamalıdır.

Başvuru süreci devam eden, ya da kısa bir süre önce tescillenmiş olan patentlerin ve geçersiz olduğunu gösteren güçlü bir argümanın varlığı halinde (örneğin, farkında olduğunuz önceki teknik ya da sizin daha eski tarihten beri üretim yaptığınız bir ürün/cihaz nedeniyle), patente itiraz etmeyi düşünebilirsiniz. Türkiye'de 6769 sayılı Sınai Mülkiyet Kanunu ile birlikte belgeye belge ilanından itibaren 6 ay içinde itiraz etmek mümkündür. Kanunun yürürlüğe girdiği 10.01.2017 tarihinden önceki başvurular için ise araştırma raporu ve sistem tercihinin ilanından itibaren 6 ay içerisinde görüş ve itirazların sunulması mümkündür. Argüman olarak sunulacak karşıt görüş ve belgelerle birlikte Kuruma itiraz edildiği araştırma/inceleme uzmanının bilgisine sunulmaktadır. Uluslararası alanda ise, Avrupa Patent Bülteni'nde Avrupa patentinin verilmesinin ilanından itibaren dokuz ay içinde itiraz edilmesi gerekmektedir. Bir itiraz, patentin iptal edilmesine veya istemlerin değiştirilmesine neden olabilir veya patent onanabilir. Ancak itiraz sürecinin ya da mahkeme sürecinin de kısa bir süreç olmayacağı göz önünde bulundurulmalıdır. EPO Teknik Temyiz Kurulunun nihai karar vermesi, itirazın dosyalanmasından itibaren 5-6 yıl veya daha uzun sürebilmektedir.

\section{Uluslararası Başvuru Süreçleri}

Patentler ulusal koruma sağlamaktadır. Başka bir ifade ile Türkiye'de patent koruması, yalnızca Türkiye sınırları içinde koruma sağlayacaktır ve başka hiçbir ülkede herhangi bir koruma sağlamayacaktır. Uluslararası patent stratejisinin erken bir aşamada değerlendirilmesi önemlidir, çünkü ilk başvurunun dosyalanması ve yayınlanmasının ardından patent kamunun bilgisine sunulmuş kabul edilmektedir. Yalnızca ilk patent dosyalama işleminden bir yıl içinde "rüçhan hakkından" faydalanarak diğer ülkelerde başvuru yapılabilir. Bu tarihten sonra ya da rüçhan gösterilmemesi halinde, buluş daha önce açılanmış olduğundan yenilik kriterini sağlayamayacaktır, dolayısıyla patent alamayacaktır. Bu kapsamda, en kısa sürede buluşun korunacağı ülkelerin belirlenmesi önemlidir. Ayrıca, tıbbi ürünlere ve cihazlara ve hatta yöntemlere ilişkin buluşların farklı ülkeler tarafından farklı şekilde ele alındığını ve bunun uluslararası korumaya nasıl yaklaşacağınız üzerinde önemli bir etkisi olabileceği de göz önünde bulundurulmalıdır.

Farklı ülkelerde koruma sağlanabilmesi için ilgilenilen her ülkeye ayrı ayrı başvuru yapılabilir. Yalnızca birkaç ülkede korumanın yeterli olacağı durumlarda, ürünün/ 
cihazın iki ya da üç ülke pazarında yer alması hedefleniyorsa, patent korumasının maliyetleri göz önünde bulundurularak, ülkelere ayrı ayrı başvurmak etkili bir yol olabilir. Bununla birlikte, bölgesel bir koruma için Avrupa Patent Ofisi (EPO) aracilığıyla tek bir Avrupa Patenti (EP) başvurusu yapılabilir ve patent koruması talep edilen EP üye devletleri belirlenebilir. Patent başvurusu EPO tarafindan incelenir ve patent verildikten sonra, belirtilen her üye devlette ulusal patent haline dönüştürülür.

Bir başka uluslararası patent başvuru sistemi de PCT başvurusu yapmaktır. PCT Avrupa patentinin aksine bir tescil sistemi değildir, başvuru sistemidir. Sadece araştırma ve talep ediliyorsa incelemenin tüm ülkelerde ortak kabul görecek şekilde gerçekleştirilmesi temeline dayanan bir sistemdir. Bu sayede, rüçhan hakkının yanı sıra buluşun diğer ülkelerde korunmasına değer olup olmadığına ilişkin araştırma raporu ve yazılı görüş elinizdeyken ilk başvurudan itibaren 30 ay sürede hangi ülkelerde başvurunun devam edeceğine karar verilir ve "ulusal fazda" ülkelerde ayrı ayrı sonuçlanır.

Ürün geliştirme ve bunun tekeli için yapılan çalışma$\mathrm{da}$, ürünün üretilmesi ya da pazarlanması için farkIı ülkelere de açılımın planlanması halinde bu ülkeler için ayrı araştırmalar gerçekleştirilmelidir. Aranan ülke sayısı arttıkça, tanımlanacak ve gözden geçirilmesi gereken belge sayısı (patent aileleri) de artacaktır.

Teknolojik gelişmeler göz önünde bulundurulduğunda, uzak doğuda patentin araştırılması özellikle de bu ürününüz için önemli bir hedef pazar olacaksa, ihtiyatlı olabilir. Örneğin, Japonya'da arama, dille ilgili sorunun yanı sıra belgelerin sınıflandırma sisteminin de farklı olması sebebiyle daha fazla efor gerektirebilir. Günümüzde patent belgelerinin internet üzerinden mekanik çevirileri mevcut olabilmektedir.

\section{Tıbbi Cihazlara illişkin Patent Başvurularında Dikkat Edilmesi Gereken Hususlar}

Bir buluşun patent alabilmesi için; başvuru unsurlarının tam olması, koruma kapsamının açık olması, korunması istenilen teknik özelliklerin yeni olması, buluş basamağı içermesi ve sanayiye uygulanabilir olması şarttır.

Kanun gereğince, "insan veya hayvan vücudunun cerrahi veya terapi ile tedavi yöntemleri ve insan veya hayvan vücudu üzerinde uygulanan teşhis yöntemleri” için patent verilemez. Bununla birlikte, bu yasak “ürünlerden, özellikle madde veya bileşimden, bu yöntemlerden herhangi birinde kullanılmak" için geçerli değildir. Bu istisna Avrupa Patent Sözleşmesinin 53c Maddesinde de aynı şekilde açıklanmaktadır. ${ }^{[22]}$
Hekimlerin her zaman tedavi yöntemini seçiminde özgür olmaları gerektiği yorumu ile patent rejiminin çok yönlü boyutları değerlendirildiğinde, tıbbi, cerrahi ve tedaviye ilişkin yöntemlerin hariç tutulması fikri ortaya çıkmıştır. Buluşu yapana ödül verilen patent hakkı ile topluma sağlanacak fayda arasındaki denge değerlendirildiğinde etik kaygılarla birçok ülkede teşhis ve tedavi yöntemlerinin patentlenebilir konuların dışında tutulmasına sebep olmuştur.

Bir usulün tıbbi tanı, tedavi ya da cerrahi metotları içerip içermediği değerlendirmesinde uluslararası alanda kullanılan kriterler aşağıda sıralanmıştır. Bu kapsamda usulün;

- uygulaması için bir tıp doktoru ya da veteriner hekimin gerekip gerekmediği,

- canlı bir insan ya da hayvan vücudu üzerinde uygulanıp uygulanmadığı,

- amacının teşhis, tanı veya cerrahi müdahale olup olmadığı,

- (bir önceki madde kapsamında) amacının kozmetik olup olmadığı,

- vücut içinde mi gerçekleştirildiği ya da bir örneğin alınarak dışarıda gerçekleştirilip gerçekleştirilmediği,

- veri toplanması ve incelenmesi; normal değerlerle karşılaştırılması ve sapmaların belirlenmesi gibi işlem adımları içerip içermediği,

- tıbbi cihazın kullanımı dolayısıyla girişimsel olup olmadığı, gibi konular değerlendirilmelidir.

Bu şekilde bir yöntemin ülkemizde ve birçok ülkede patentle korunması mümkün olmayacaktır. Fakat Amerika Birleşik Devletleri, Avustralya ve Kanada gibi bazı ülkelerde teşhis tedavi usullerinin de korunması mümkün olabilmektedir. Tıbbi cihazın teknik özelliklerinin belirtildiği, ürünü tanımlayan istemler, bu hariç tutmanın dışında sayılmaktadır. Başka bir ifade ile kanun sadece usullere ilişkin bir kısıt oluşturmakta, ilaçlar, maddeler, aletler, aparatlar, cihazlar için patent koruması mümkündür. Bu sebeple tıbbi cihazın; ürüne veya aparata ait teknik özellikleri açıklanarak patent koruması alınması daha doğru olacaktır. Ürüne ait teknik özellikle mutlaka "ürün istemi" kriterlerine uygun olarak düzenlenmelidir. Açıkça yazılmasa dahi uygulamanın doğası gereği teşhis, tedavi usulü ya da cerrahi usul niteliğinde olabilecek uygulamalarda, bunların hariç tutulduğu açıkça patentte belirtilmelidir.

Bunun yanı sıra istem yazımında yeni olduğu iddia edilen teknik detaylar sıralanırken belirtilen tüm unsurlar da tarifname tarafından desteklenmeli, mümkünse bu parametrelerin, değerlerin, malzemelerin ya da 
teknik özelliklerin seçimindeki tercih sebepleri tarifnamede sunulmalıdır.

Genellikle ilaç başvurularında, etkin maddelerin kullanımına ilişkin ifadeler ve biyolojik/terapötik etkinin nasıl bulunduğunu gösteren deneylerin raporları yer alır. Benzer şekilde tıbbi cihaz için seçilen parametreler de deney sonuçları ile desteklenebilir. Bu sonuçlar gerekli olmasa dahi özellikle bir aralıktan seçilmiş teknik detayların kanıtı olarak gösterilebilir. Bu kanıtlar, araştırmayı yapan uzman başvuruda belirtilen etkilere ilişkin şüphe duyarsa başvurulabilecek bir kanıttır.

\section{Çalışan Buluşları ve Yülkseköğretim Kurumlarında Gerçekleştirilen Buluşlar}

Bir fikrin Ar-Ge süreçlerini tamamlaması ve pazara ulaşması bir döngü olarak nitelendirilebilir. ${ }^{[23]}$ Pazar ihtiyaçları ve sürekli iyileştirme kavramı çerçevesinde nihai ürünün ardından yeniden araştırma aşamasına geçilebilmektedir. Ar-Ge faaliyetleri kapsamında gündeme gelen ilk başlıklar arasında bir prototipin tasarlanması ve ön klinik araştırmaların tamamlanması karşımıza çıkmaktadır. Bir patent başvurusu için nihai bir ürün gerekmemektedir ve yalnızca fikir aşamasında da patent alınabilir. Bu erken evrede sınai mülkiyet hakları için bir analiz yapılması önemli ve uygundur. Sınai mülkiyet hakları kapsamında yeni ürün tasarımları, ürünün teknik unsurları ve fonksiyonları korunabilir. Yeni tıbbi cihazınızı nasıl en iyi şekilde koruyacağı ya da tekel hakkının yatırıma değer olup olmadığı karar vermek için ön araştırmanın önemi büyüktür. Patent başvurularının tescil oranları göz önünde bulundurulduğunda, araştırma ve geliştirmenin üçte birinin şimdiye kadar yapılmış buluşların tekrarı olduğu söylenebilir.

Cihaz geliştirme aşamasında dikkat edilmesi gereken bir diğer husus da çalışan buluşları ve buluş gizliliğidir. Yeni bir tıbbi cihaz tasarlanırken, projeye katılanların, tıbbi cihazın şeklini gösteren kavram, teknik ayrıntılar ve tasarım çizimleri veya diğer belgeleri gizli tutmaları gerektiğini anlamaları önemlidir. Bunun nedeni, bu gizli bilgilerin toplumun erişimine açılması durumunda sınai mülkiyet korumasından faydalanamayacak olmasıdır.

Genel olarak, çalışanların işyeri faaliyetlerine ilişkin çalışmaları kapsamında oluşan buluşlara ait haklar işverene aittir. ${ }^{[24,25]}$ Çalışanın buluşlarına ilişkin yönetmelikte; çalışan buluşu, bir işletme veya kamu idaresinde yükümlü olduğu faaliyeti gereği gerçekleştirdiği veya işyerinin faaliyet gösterdiği alanlar içinde, büyük ölçüde işletme veya kamu idaresinin deneyim ve çaIışmalarına dayanarak, iş ilişkisi sırasında yaptığı buluşlar olarak tanımlanmıştır. Aynı yönetmelik ve kanunun ilgili maddeleri gereğince her iki taraf da buluşun gizliliğine ilişkin her türlü önlemi almakla yükümlüdür. Çalışanın elde edilen sınai mülkiyet hakkını otomatik olarak kendi üzerine alması mümkün değildir. Ancak buluşun "serbest buluş" olması ve bu hakların buluşu yapana verilmesi, işverenin hizmet buluşu üzerindeki hak talebinde bulunmadığını belirtmesi ile gerçekleşebilmektedir. Fikri mülkiyet hakları genellikle yalnızca yazılı olarak aktarılabilir, bu nedenle mülkiyet ve görev ayrıntılarının yazılı bir sözleşmeyle açıkça resmileştirilmiş olması gerekir. İşveren hizmet buluşu üzerinde tam ya da hak talep ederse, çalışan makul bir bedelin kendisine ödenmesini işverenden isteyebilir.

SMK ile gündeme gelen bir diğer başlık da Yükseköğretim Kurumlarında gerçekleştirilen buluşlardır. Üniversitelerimizdeki patent potansiyeli harekete geçirmek amacıyla yapılan bu düzenleme ile akademisyenlerin ve öğrencilerin buluşlarını üniversiteye gecikmeksizin bildirme yükümlülüğü, üniversitenin ise patent başvurusu yapma yükümlülüğü ve patenti ticarileştirmesi gelirin en az üçte birinin akademisyene verilmesi söz konusudur.

$\mathrm{Bu}$ kapsamdaki tüm düzenlemeler SMK'nin 113-122'nci maddelerinde ve “Çalışan Buluşlarına, Yükseköğretim Kurumlarında Gerçekleştirilen Buluşlara ve Kamu Destekli Projelerde Ortaya Çıkan Buluşlara Dair Yönetmelik" ile düzenlenmiştir. ${ }^{[24,25]}$

\section{SONUÇ ve DEĞERLENDIRME}

Tıp teknolojilerinin tüm dünyada ve ülkemizde çalışmaları çok uzun yıllara dayansa da ilerlemeler 20. yy'ın son çeyreğinden itibaren gerçekleşmiş ve ülkemizde de özelikle 2000'li yıllardan sonra bu sektör tanınmaya başlanmıştır. Sektöre yönelik maddi ve insan kaynağı yatırımlarının artmaya başladığı günümüzde, tüm teknolojik alanlarda Ar-Ge faaliyetlerine ve inovasyona verilen önemin artışıyla, bu alandaki patent başvurularının da artması kaçınılmaz olmuştur. Ülkemizin de tüm dünyada olduğu gibi biyomedikal sistemlere yönelik Ar-Ge faaliyetleri her geçen yıl artarak devam etmektedir. Son 10 yılda tıbbi cihaz sektöründe patent başvurularındaki artışa ek olarak bu yıl sağlık sektörüne ilişkin başvuruların pandemi dolayısıyla da artış göstereceğini tahmin etmek zor değildir.

Patent korumasıyla araştırma faaliyetlerinde rakiplerin bir adım önüne geçmek, piyasada tanınır olmak, taklidin önlemesi gibi birçok fayda sağlamak mümkündür. Fikirlerin bir patente dönüşmesi yalnızca yeniliği değil, teknoloji transferini, rekabeti ve bilginin yayılmasını da teşvik etmektedir. Patent ve faydalı model süreçlerin kavranmasının da biyomedikal sistemlere ilişkin faaliyetler için yol gösterici nitelikte olacağı değerlendirilmektedir. 
Ar-Ge faaliyetlerini sürdüren kişilerin başvuru hazırlarken en fazla dikkat edilmesi gereken husus ön araştırmadır. Ön araştırmanın önemi hem araştırmanın yolunun çizilmesi esnasında hem de patent başvurusunun hazırlanması aşamasında karşımıza çıkmaktadır. Ücretsiz bilgi kaynağı olan patentlere erişim sayesinde mevcut teknolojileri anlamak ve onları geliştirmek esastır.

Bu makalede tıbbi cihaz sektörünün patent sistemi açısından değerlendirmesi yapılmış ve bu değerlendirmelerin tıbbi cihaz alanında yenilikçi fikirlere sahip araştırmacılara yol göstermesi hedeflenmiştir. Temel kavramlar ve patent sınıflandırmasına ilişkin bilgilendirmenin ardından mevcut durumun ortaya koyulabilmesi amacıyla patentlere ilişkin istatistiksel veriler sunulmuştur. Ayrıca, patentlenebilirlik kriterleri ve patentlenebilirliğin istisnaları açılarından da tıbbi cihaz sektörüne ve pazara ilişkin özel durumlara yer verilmiştir. Çalışma genelinde çoğunlukla patent perspektifinden teşhis, tedavi usulleri ile cerrahi usullerin patentlenememesi hususlarına dikkat çekilmiştir.

\section{KAYNAKLAR}

1. WIPO (Dünya Fikri Mülkiyet Teşkilatı). What is Intellectual Property? [Fikri Mülkiyet Hakları nedir?]. http://www.wipo. int/about-ip/en/

2. Fikri Mülkiyet. 20 Mart 1883 tarihli Paris sözleşmesi. https:// fikrimulkiyet.com/mevzuat/paris-anlasmasi/

3. Fikri Mülkiyet. 9 Eylül 1886 tarihli Bern Anlaşması. https:// fikrimulkiyet.com/mevzuat/bern-anlasmasi/

4. Türk Patent ve Marka Kurumunun Kuruluş ve Görevleri. Bakanlıklara Bağlı, İlgili, İlişkili Kurum ve Kuruluşlar ile Diğer Kurum ve Kuruluşların Teşkilatı Hakkında 4 Numaralı Cumhurbaşkanlığı Kararnamesi, m.358 - m.383 hükümleri. 15/7/2018 tarihli ve 30479 sayılı Resmi Gazete. https://www. mevzuat.gov.tr/MevzuatMetin/19.5.4.pdf

5. Fikir ve Sanat Eserleri Kanunu. Sayı: 5846, Kabul: 5/12/1951. https://www.mevzuat.gov.tr/MevzuatMetin/1.3.5846.pdf

6. Patent, ihtira beratı. Türk Dil Kurumu, Güncel Türkçe Sözlük. https://sozluk.gov.tr/

7. Bora Orçun C. Türkiye'de Biyomedikal Sistemlere Yönelik Patent Faaliyetlerinin Analizi ve Uluslararası Ölçekte Değerlendirilmesi, Türk Patent ve Marka Kurumu Sınai Mülkiyet (Patent). Uzmanlık Tezi, 2017.

8. Sağlık Bakanlığı, Türkiye İlaç ve Tıbbi Cihaz Kurumu. Türkiye Tıbbi Cihaz Sektörü Strateji Belgesi ve Eylem Planı, 20162020; Kasım 2015. https://titck.gov.tr/Dosyalar/TibbiCihaz/ ProjeveStrateji/T\%C4\%B1bbi\%20Cihaz\%20Sekt\%C3\%B6r\%20 Stratejisi\%20Belgesi\%20ve\%20Eylem\%20Plan\%C4\%B1\%20 25.11.2015.pdf
9. Ankara Kalkınma Ajansı. Ankara Tıbbi Cihazlar Sektör analizi Türkiye Kalkınma Bankası A.Ş. Ekonomik ve Sosyal Araştırmalar Müdürlüğü; Ocak 2013. https://www. ankaraka. org.tr/archive/files/yayinlar/ankara-tibbi-cihaz-analiz.pdf

10. Mirza Z. Road to Medical Innovation \& Access: from a rearview mirror. Global Health Histories Seminar Series, Geneva, WHO Headquarters, 11 Temmuz 2012.

11. WCG. MAGI's History of Clinical Research Milestones. https://www. magiworld.org/Milestones? search=patent\&dat $\mathrm{e}=$ All\&anchor $=$ word

12. WIPO Patent Cooperation Treaty Yearly Review, 2020. https:// www.wipo.int/edocs/pubdocs/en/wipo_pub_901_2020.pdf

13. EPO Patent Index and statistics (EPO Patent istatistikleri). https://www.epo.org/news-events/press/annual-results.html

14. MedTech Europe. The European Medical Technology Industry in figures 2020. https://www.medtecheurope.org/ wp-content/uploads/2020/05/The-European-MedicalTechnology-Industry-in-figures-2020.pdf

15. Akers N. Patent Specification as Sources of Information. Informa UK Ltd.; 2006. p.12.

16. Council of Europe. European Convention on the International Classification of Patents for Invention; 1954. https://rm.coe. int $/ 168006457 d$

17. WIPO (World Intellectual Property Organization). Strasbourg Agreement Concerning the International Patent Classification of March 24, 1971, as amended on September 28, 1979. http://www.wipo.int/treaties/en/text.jsp?file_id=291858

18. OECDiLibrary. OECD Science, Technology and Industry Scoreboard 2015 Innovation for growth and society: Innovation for growth and society. Paris: OECD Publishing; p.232. Crossref

19. Patent/Faydalı Model Bilgilendirme, Patent-Faydalı Model Başvuru Kılavuzu. https://www.turkpatent.gov.tr/ TURKPATENT/resources/temp/522B990B-E529-4378-828766E77494B4FA.pdf

20. Google Patents (araştırma ara yüzü). https://patents.google. com/

21. Espacenet Patent Search. (Avrupa Patent Ofisi patent araştırma ara yüzü). https://worldwide.espacenet.com

22. The European Patent Convention, 53.c (Avrupa Patent Sözleşmesinin 53.c Maddesi). https://www.epo.org/lawpractice/legal-texts/html/epc/2016/e/ar53.html

23. European IP Helpdesk (Avrupa Fikri Mülkiyet Yardım Masası). http://www.iprhelpdesk.eu/library

24. Sınai Mülkiyet Kanunu; Madde 113-120. Sayı: 6769 Kabul: 22.12.2016. https://mevzuat.gov.tr/MevzuatMetin/1.5.6769. pdf

25. Çalışan Buluşlarına, Yükseköğretim Kurumlarında Gerçekleştirilen Buluşlara ve Kamu Destekli Projelerde Ortaya Çıkan Buluşlara Dair Yönetmelik. 29.09.2017 Tarihli, 30195 Sayılı Resmi Gazete. https://resmigazete.gov. tr/eskiler/2017/09/20170929-6.htm 